
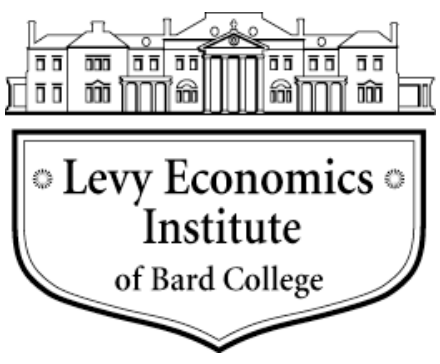

Working Paper No. 796

\title{
Minsky and the Subprime Mortgage Crisis: The Financial Instability Hypothesis in the Era of Financialization
}

by

\author{
Eugenio Caverzasi* \\ University of Ancona
}

\section{April 2014}

*eu.caver@gmail.com

The Levy Economics Institute Working Paper Collection presents research in progress by Levy Institute scholars and conference participants. The purpose of the series is to disseminate ideas to and elicit comments from academics and professionals.

Levy Economics Institute of Bard College, founded in 1986, is a nonprofit, nonpartisan, independently funded research organization devoted to public service. Through scholarship and economic research it generates viable, effective public policy responses to important economic problems that profoundly affect the quality of life in the United States and abroad.

\author{
Levy Economics Institute \\ P.O. Box 5000 \\ Annandale-on-Hudson, NY 12504-5000 \\ http://www.levyinstitute.org
}

Copyright (C) Levy Economics Institute 2014 All rights reserved 


\section{ABSTRACT}

The aim of this paper is to develop a structural explanation of the subprime mortgage crisis, grounded on the combination of two apparently incompatible financial theories: the financial instability hypothesis by Hyman P. Minsky and the theory of capital market inflation by Jan Toporowski. Our thesis is that, once the evolution of the financial market is taken into account, the financial Keynesianism of Minsky is still a valid framework to understand the events leading to the crisis.

Keywords: Hyman Minsky; Financial Instability Hypothesis; Jan Toporowski; Capital Market Inflation; Financialization; Financial Crisis; Subprime Mortgage Crisis

JEL Classifications: B2, B5, E44, G01 


\section{INTRODUCTION}

The aim of this paper is to develop a structural explanation of the subprime mortgage crisis that hit the U.S. economy in 2007. To reach our goal, it will be necessary to disclose the features and the reasons of the particular indebtment dynamics of the US private sector. In trying to do so, we rely mainly on the works of two distinct scholars : Hyman P. Minsky and Jan Toporowski. The theories of the two authors appear, at a first look, contrasting. However, our thesis is that, not only the Financial Instability Hypothesis (Minsky, 1986), and more generally the "financial Keynesianism"" of Minsky, can be combined with the theory of Capital Market Inflation (Toporowski, 2000), but jointly, the two theories can provide for a sound explanation of how the crisis endogenously emerged from the U.S. economic system. Indeed, we firmly reject the idea that "black swans" (Taleb, 2010) or exogenous shocks of any type might have caused the crisis. We believe that the pathogens which led to the crisis were congenital to U.S. capitalism and that the bursting in the mortgage market happened for specific reasons. This is what is meant in this paper by "structural interpretation": the identification and the understanding of the endogenous forces which made the U.S. economy progressively reach an unsustainable financial position, making the crisis an inescapable event.

A very useful perspective to use when analyzing the indebtment (and credit) dynamics which led to the crisis is the one put forward by Josef Steindl in his insightful theory of "enforced indebtedness" (Steindl, 1952). A very simple manipulation of national accounting, based on a basic disaggregation of the private sector among households and firms, was the starting point of this analysis:

$\mathrm{S}_{\mathrm{F}} \equiv \mathrm{I}-\mathrm{S}_{\mathrm{H}}+(\mathrm{G}-\mathrm{T})+(\mathrm{X}-\mathrm{M})$.

Summarizing the theory, according to Steindl, the saving decisions of households have a direct impact on the level of indebtedness of firms: the more households save, the more firms become indebted. Less household spending means lower revenues for the firms, whose sources of internal finance (i.e. retained earnings) diminish, forcing them to become indebted while financing their investment decisions. This tendency appeared reversed in the events that led to the crisis of 2007. Indeed the financial position of firms was stable while debt piled up in the household sector (see fig. 1). In developing our structural interpretation, we will try to assess the causes of this particular debt dynamic.

1 This, according to Papadimitriou and Wray (1997), was the definition preferred by Minsky, for his own work, rather than post-Keynesian. With it we refer to Minsky's whole economic theory, seen as an interpretation of the The General Theory of John Maynard Keynes, as explained in section 1.2. 
Figure 1 Debt over GDP ratios. Dashed line: households; black line: business sector.

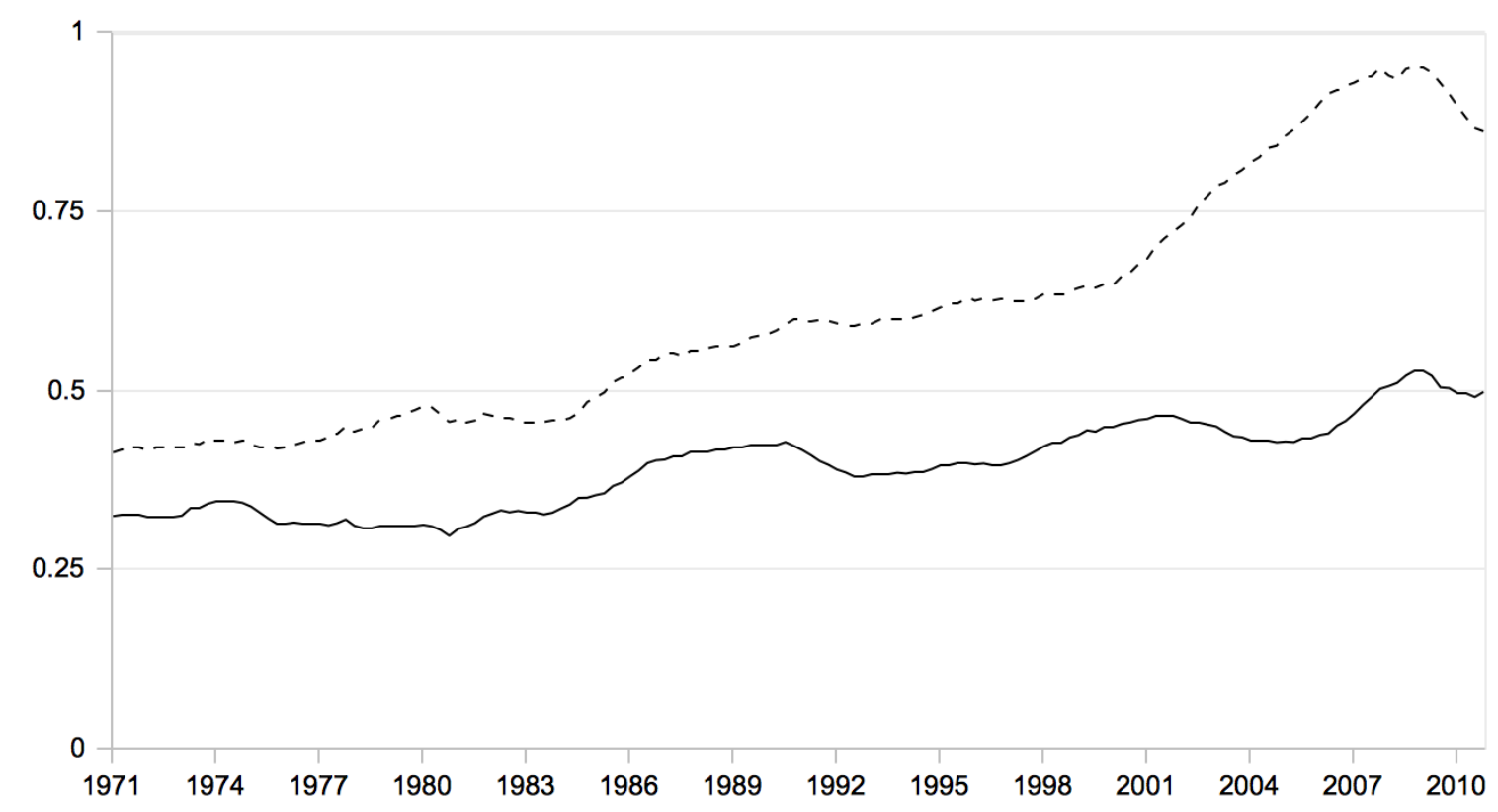

Source: Federal Reserve Economic Data

The outline of the paper is as follows. First, we provide for an overview of Minsky's contribution: the Financial Instability Hypothesis (FIH) and Financial Keynesianism. In doing so, we enter the debate over the coherence between the FIH and the subprime crisis. Second, we revert to the theory of Capital Market Inflation (CMI) by Toporowski. Then, in Section 3, we combine the two theories and develop our structural explanation of the crisis. We then recall the main features of the crisis and some of the peculiarities of the U.S. economy to underline the coherence between our analysis and the economic events investigated. Finally, Section 4 summarizes the main conclusions and results of this work.

\section{MINSKY'S CONTRIBUTION}

The importance of Minsky's work is universally recognized within the heterodox (especially post-Keynesian) tradition for its capacity to shed light on the dynamics of the financial system, particularly with respect to their influences on the business cycle. Furthermore, his analysis made a substantial resurgence with the latest crisis, even beyond the heterodox academic world. However, the extent to which the Financial Instability Hypothesis can provide an explanation to the subprime crisis is at the center of a debate, which, we believe, 
is due to an underlying interpretational issue that will be presented in the following section. In reading Minsky's contribution, one can either focus exclusively on his FIH as a financial theory of the business cycle based on firms' investment and financing decisions, or on financial Keynesianism as a broader theoretical framework.

Our point of view is that on the one hand, the FIH embodies aspects strictly linked to the economic context Minsky was witnessing. These "contingent" features result in a prima facie incompatibility of several of the main conclusions of the author with recent economic events. On the other hand, the theoretical analysis of Minsky goes far beyond the FIH with its most contingent aspects, and his analytical framework allows us to identify both the structural elements of modern crises and their causes.

We believe that it is of little use to detach economic analysis from the institutional and social settings characterizing the economy in which the events under analysis occurred. Because some of these settings have changed since the time Minsky conceived his theories, it is important to take into account their main aspects of novelty, in particular - as it will be shown in the following sections - those referring to the premises of the FIH. This is why we revert to the analysis of Toporowski, because we believe that his theory of CMI sheds light on the dynamics characterizing modern financial markets and on their influences on the real side of the economy. The next two sections will be devoted to analyzing the work of Minsky under two distinct perspectives: one limited to the FIH and the other enlarged to financial Keynesianism, followed by a section which includes a brief overview of Toporowski's theory of CMI.

\subsection{The FIH: a Component of Minsky's Financial Keynesianism}

The FIH is an endogenous theory of the business cycle centered on the analysis of the financial structure of the economy. According to Minsky, within the economy, there are forces that, during a period of tranquility — meant as a more or less stable growth — lead the system towards instability (Minsky, 1985). Referring to the national accounting manipulation in the introduction, the $\mathrm{FIH}$ focuses on the role of $I$ and $\mathrm{S}_{\mathrm{F}}$. The latter is supposed to decrease during a boom. In this analysis, firms, under uncertainty, choose the level of investment comparing two ${ }^{2}$ elements in Minsky's two price theory. On the one side, the expected stream of returns diminishes by a discretional margin, which represents a "cushion of safety" (see Kregel, 2008) to protect firms against the possibility of wrong

2 This double focus is expressed by Minsky, through a two-price theory which recalls Tobin's q, from which it differs for two main reasons. First, Minsky takes into account the source of finance, since he dismisses the Modigliani Miller theorem. Second, he takes into account uncertainty. 
forecasting and of inability to repay the debt (borrower's risk). On the other side, the cost of the capital asset, which — whenever firms have to resort to external finance — increases together with the extent of the loans, since banks claim a premium against the possibility that the borrower defaults on its debt (lender's risk). Broadly speaking, the bigger the loan, the higher the possibility ${ }^{3}$ of default and subsequent losses, and therefore the required risk premium.

Hence an investment decision directly leads to a stream of revenues and a stream of financial commitments. As long as revenues exceed commitments, the economy is stable. Vice-versa, a crisis can occur. This led Minsky to formulate his famous taxonomy of financial positions, in which he distinguishes among hedge, speculative and Ponzi units. In the first case, ${ }^{4}$ in any moment, firms' expected money inflow exceeds their financial commitments. In the second case, revenues are enough to repay interest but not the part of the principal supposed to be paid. Hence it becomes necessary to roll over the debt. Finally, Ponzi units are those needing to borrow additional money, or to sell assets, since revenues are lower than interest payments. The stability of the economy depends on the relative presence of each of these types of units, and the more hedge units are present, the more stable will be the economy.

According to Minsky, after a prolonged period of tranquility, units' expectations both firms' and banks' - tend to become more and more optimistic, and the margins of safety narrow and speculative and Ponzi finance become consuetudinary. Then something happens; this could be, for example, an increase in the interest rate either due to tighter monetary policy or endogenous forces, or a change in expectations. As a result, speculative and Ponzi units are no longer able to meet their financial commitments, leading them to either default or sell assets. This leads to debt deflation and crisis, which spreads due to the intercorrelation among balance sheets.

In our opinion, limiting the analysis of the work of Minsky to the FIH does not give justice to the work of the author. The FIH is indeed a corollary of a broader theoretical framework on the macrodynamics of financially complex market economies.

In a recent article, Paul Krugman (Krugman, 2011) divided Keynesians into two groups. The first (the "Chapter 12ers") focuses on radical uncertainty, while the second (the "Book 1ers") underlines the refutation of "Say's Law" and the importance of aggregate demand. Minsky (as do many post Keynesian economists) completely overcomes this

3 This immediately recalls Kalecki’s principle of increasing risk (see Kalecki, 1937).

$4 \quad$ Here we refer to the exposition of Minsky (1992) elsewhere the taxonomy was presented in slightly different terms by the author. 
dichotomy. Should we pick just one of the 24 "General Theory"'s chapters", he might rather be classified as a Chapter 17.

His financial Keynesianism indeed springs from a personal interpretation of the General Theory, whose main focus is on Chapter 17, where Keynes displays his theory of portfolio choice underlying the key role of liquidity preferences. Through this financial perspective, Minsky then reads the General Theory, undoubtedly enclosing in his analysis Chapter 12 and Book 1. What Minsky did was to bring back from Keynes's "Treatise on Money" crucial "monetary [and financial] detail" that, in the General Theory, Keynes let fall (Macedo-e-Silva, 2009) “into the background” (Keynes1937, p vii).

Applying this theoretical framework to the analysis of the form of capitalism he was witnessing allowed Minsky to identify the existence of a "Wall Street Paradigm" (Minsky, 1975): a capitalist system with complex financial markets, where different portfolio choices and different sources of credits have different impacts on economic activity, and in which, of course, stability could be destabilizing, as described by the FIH. This was opposed to the village fair one, typical of classical and neoclassical economics - in practice a barter-based economy.

\subsection{Was it a Minsky Moment?}

The expression "Minsky moment" is broadly used to define a situation in which units (traditionally firms) which became over-indebted due to the optimism caused by a prolonged period of tranquility, need to sell their assets to pay their financial commitments. This, if government does not intervene, can clearly cause a Fisherian debt deflation, and lead to a generalized economic crisis. One of the most influential post-Keynesian economists, Paul Davidson (2008), openly questioned the possibility of defining the subprime crisis as a Minsky moment. The author identifies, in the shift of the economy from hedge to Ponzifinance, a necessary precondition for a Minsky moment to take place. This could not have occurred in the crisis of 2007, since, according to Davidson's explanation, the taxonomy of financial positions simply cannot be applied to the housing market. Speculative finance is based on a premeditated decision to roll over a debt, an eventuality which, according to the author, was excluded by the specific contractual forms of that market. According to Davidson, speculative finance necessitates a premeditated decision to roll over a debt, and this could not be the case in the real estate market, since the subprime mortgage contracts

\footnotetext{
${ }^{5}$ The "General Theory of Employment, Interest and Money" is a six-volume, 24-chapter series written by John Maynard Keynes and published in 1936.
} 
include a strong penalty in such cases. Moreover, even in the case the borrower was unaware of it, or had he accepted it, a second mortgage would not have been granted to a subprime borrower. Davidson's explanation for the crisis is that it was the result of an attempt to securitize illiquid assets, an action allowed by the deregulation of financial markets, realized through the repeal of the Glass-Steagall Act.

Another prominent post-Keynesian scholar, Jan Kregel, reaches the same conclusion, albeit under a different perspective. Kregel (2008) recognizes the presence of a Ponzi scheme in the subprime mortgage market, due to the "likelihood that the cash commitments can only be met by increased borrowing or refinancing at some future date" (p.14, Ibid). However, in his view, the presence of a Ponzi scheme was not the result of endogenous forces, as in the analysis of Minsky. It was determined by a structural change of the financial system, which caused the detachment of the issuer of the debt, the evaluator of the credit worthiness and the units running the lender's risk. Banks indeed are no more responsible for the evaluation ${ }^{6}$ of the risk, since their profits are assured by the sale of securitized mortgages, and do not depend any more on the interest rate inflow from the loan. This led to the Ponzi scheme which caused the subprime crisis. Wray (2012) too states that the crisis is the result of a structural change in the U.S. economy, and therefore dismisses the possibility of "black swans." However, he puts forward a Minskyan interpretation of what happened. His idea is that the excess of optimism - motivated by the belief in the Great Moderation led financial institutions to undertake riskier and riskier financial practices, heading the economy toward the crisis. "So, it is completely appropriate to give credit to Minsky's foresight" (Ibid, p.4).

Other authors suggest what we could define as a "same scenario, different location" perspective: a Minsky moment occurred, albeit not where Minsky theorized it would. For example, Dymski(2010) enters this debate acknowledging the importance of the contribution of Minsky in the understanding of the features of the crisis. However he recognizes that what happened in the 2007 had peculiarities which made it differ from the dynamic depicted in the FIH. Dymski identifies three original elements: new banking regulation, inclusion and consequent financial exploitation of minorities in the real estate market, and U.S. current account deficit, which were absent at the time Minsky developed his hypothesis and hence did not include in his theory. Also, Bellofiore and Halevi (2009) offer a Minskyan interpretation of the crisis "sub condicione." Similarly to Dymski, they

\footnotetext{
6 Furthermore the profits of the rating agency - responsible for the evaluation of the risk - do not depend
} directly on the actual solvency of the borrower. 
identify the elements of novelty which need to be taken into account to update the FIH and to make it coherent with the new form of capitalism that emerged in the U.S. in the second half of the 1990s. This "new capitalism" (as defined by the authors) is described through a historical perspective putting emphasis on the metamorphosis of the economic system, in which industry and labor became subordinated to finance. Hence, for the FIH to "survive" in this new capitalism, it is necessary to take into account some key elements of novelty. First, contrary to the one described by the $\mathrm{FIH}$, the boom did not occur in relation to real investment. Second, aggregate demand was no more dependent on aggregate investment, because of the rise of debt-financed consumption. Last, the increase in prices associated with the boom was independent of wages, and determined by raw materials' prices. Given these significant transformations, the two authors believe that "A Minsky dynamics has, indeed, occurred but elsewhere and with a different set of modalities compared to those envisaged by the author" (Bellofiore and Halevi 2009, p.16).

We believe that this controversy, whether this crisis is indeed a Minsky moment or not, is deeply linked to the interpretational issue we recall above. If the FIH is slavishly taken as originally presented by Minsky, in particular with respect to his investment theory, and overlapped with a summary of the main events which characterized the subprime crisis, a certain amount of circumstances and features, over which the evolution of the crisis deviates from the dynamic depicted in the FIH, will undoubtedly emerge, since - as underlined by most of the authors of our literature review - the crisis did not take place in relation to the financing of real investment. In this case, the conclusion would be that it was not — at least not exactly — a Minsky moment (as in the analysis of Davidson). Our perspective differs substantially. We believe that the analysis of Minsky goes far beyond his theory of investment and that it is possible to use his analysis as a framework to understand how the financial system can overcome its limits and how this can affect the real economy (as Bellofiore and Halevi, 2009; Dymski, 2010 ; and Wray, 2012 appear to have done). ${ }^{7}$

$7 \quad$ The possibility of using the analytical framework conceived by Minsky to a different context than firms' investment decision does not represent a novelty. For example it has been used analyse the structure of the financial system and its possible reforms (e.g. Kregel, 2010) or international economic dynamics (e.g. Galbraith and Munevar Sastre, 2010). 
One characterizing feature of the recent form of US capitalism is undoubtedly the dramatic increase in the role played by finance. This metamorphosis — which is commonly referred to as "financialization" - created the new environment from which the crisis emerged. In the next paragraphs, we will try to demonstrate that, even considering the aspects of the financialization, which appear to be mostly in contradiction with the FIH, it would still be possible to use the theoretical framework developed by Minsky to understand the 2007 crisis.

Before doing so however, we want to recall that Minsky, as well, identified a new phase in American capitalism, ${ }^{8}$ which he defined as "money manager capitalism" (see Minsky, 1996). This was characterized by the following elements:

1) Almost all business is organized through corporations. 2) Dominant proportions of the liabilities of corporations are held by financial institutions[...]. 3) This involves the intrusion of a new layer of intermediation, by pension and mutual funds, into the financial structure. 4) Pension and mutual funds are bound only by contract as to what assets they can own and what activities they can engage in. 5) The stated aim of the of fund managers is to maximize the value of the investments of the holders of its liabilities. 6) The performance of a fund and of a fund managers is measured by the total revenue on assets[: dividends, interests and capital gains](Ibid, p. 363).

Some of these points recall shareholder value orientation, which is at the heart of the analyses of several authors (see Onaran et al., 2011; van-Treeck, 2009) on financialization. Once more, Minsky proved to be an acute observer ${ }^{9}$ of economic realities. However, this did not lead him to reconsider the dynamics of the FIH, which focuses on the external financing of real investment, mainly in the form of debt. This theory was developed during a different era of U.S. capitalism; an era in which the dependency of firms on bank loans for the financing of investment was still elevated. A major feature of the financialization of the economy is the shift of the source of financing from loans to equity, and this has a significative impact on the results of the FIH. In a coauthored paper, Minsky observed that "The greater the ratio of equity to debt financing, the greater the chance that the firm will be a hedge financing unit" (Delli Gatti et al., 1994). However, he never updated the FIH in light

8 The preceding stages he identifies are: 'commercial capitalism; industrial capitalism and wild cat financing; financial capitalism and state financing; paternalistic, managerial and welfare capitalism'(p. 362 Minsky, 1996).

9 However the first of this point does not correspond to reality, since small and medium enterprises still account for most of the private jobs in the U.S. and to one third of the exports United States International Trade Commission (2010). 
of this observation and of the new stylized facts regarding investment financing in a financialized economy. Probably, this is why his analysis left the space for some critique (Lavoie, 2001) and some doubt about the possibility of defining the subprime crisis as a Minsky moment.

\section{A DIFFERENT BUT COMPLEMENTARY PERSPECTIVE: THE CMI}

What emerges from our analysis of the FIH is that its most contingent features represent a major difficulty in the attempt of applying it to the actual economic situation due to the structural change that characterized the economy and led to a new form of capitalism (a process we defined as financialization). Unlike Minsky, Toporowski derived his theory of CMI (2000), directly from an insightful observation of the financial markets during this new phase of capitalism. His theory also includes the quintessential aspects of novelty of the financial system (missing in the FIH) and therefore represents a fundamental support for our theoretical analysis. In this section, we present a brief overview of the theory.

CMI could be defined as a theory of structural disequilibrium in the financial sector in its relation to the real side of the economy. The starting point of the CMI is a critique of conventional financial theories. According to Toporowski, the modern portfolio theory, the capital asset price models, the arbitrage pricing models, and the efficient market hypothesis, all focus exclusively on elements which are important only when net inflows of money into the securities market are negligible. The author distinguishes between substitution and inflow effects, stating that standard theories neglect the latter. The securities market - in the view of Toporowski - is not characterized by equilibrium, and the equality between supply and demand is only notional. When the demand for securities exceeds supply, prices rise. The increase in the level of prices leads to capital gains for the holders of the assets. This, in turn, stimulates further demand - new net inflow — from units willing to take part in the capital gains, with a given level of supply. The speculative demand hence increases together with prices, in a self-reinforcing dynamic. "The excess is then taken up by a higher turnover of the available stocks and higher stock prices, as brokers and investors are obliged to offer higher prices in order to persuade holders of stocks to sell' (Toporowski 2000, p.33 ). The reactions of the financial market to these inflationary pressures are determined by some of its peculiarities. 
Different assets have different characteristics, hence the increase in demand will inflate mostly the price of those assets without a face value - typically equities. Furthermore, the main issuers in the financial markets are financial institutions, governments and corporations. Governments have budget restrictions, while financial institutions are mainly intermediaries, which buy and issue mostly between them. Hence corporations, through equity emission, represent the sector which accounts for most of the excess of demand for securities. Furthermore, the author identifies three sets of prices in the financial markets: notional price - the price advertised by brokers in the market; actual price - the price at which securities are actually exchanged in the market; and effective price - the price of newly issued equities. The flow of funds from the financial market to the firms occurs through effective prices, which, only in a second moment - if firms issue new equities - inflates as well. According to Toporowski, the outcome of these forces was that corporations - in an attempt to take advantage of the inflated financial markets - issued equities beyond their financial needs and became overcapitalized.

In the analysis of the author, we can identify several factors explaining this behavior. First, firms discovered they could easily obtain cheap external finance by issuing a security whose return is represented in part by dividends and in part by capital gains, which - unlike the interest paid on liabilities - does not represent an outflow of money for the company. Secondly, what could have been a natural deterrent against an excess issue of equities, namely the loss of control over the company, does not represent a problem anymore. The inflow of money takes place mainly through financial intermediaries — like investment or pension funds - whose managers hardly take part in the administration of the company. Third, the new remunerations criteria, which switched from profit-related to share pricerelated, and often paid through stock options, represented an incentive for managers to follow this path. ${ }^{10}$ Finally, the exceptional inflow of capital deriving first from the rise of a privatized welfare system - which led to the pension funds - and then from the inflow of foreign capital from countries with a surplus in trade balance, fuelled further this dynamic.

Hence corporations became overcapitalized. But what was that extraordinary inflow of money used for? The most common uses of the excess capital, among which the acquisition of companies represented a safer way to enlarge business compared to entrepreneurial activity, were the decrease of debt, the acquisition of short-term financial assets - to maintain liquidity — and balance sheets restructuring

10 Hence also in the analysis of Toporowski recurs the idea of shareholder value orientation. 
Industrial regeneration is a dream of engineers, from which companies are awoken by their finance directors to face the irrefutable realities of balance sheet restructuring as the only financially viable way forward for all companies (Toporowski, 2009a, p. 151).

The easy access to funds and the high profits in the financial markets led corporations to direct their investments toward financial rather than real capital, as shown, for example, by Orhangazi (2008). Hence ultimately, the overcapitalization process resulted in a financialization of the US real sector.

\subsection{The CMI and the FMI: Main Difficulties}

The conclusions of the CMI are, at a first sight, devastating for the FIH. A direct consequence of the overcapitalization processes described by Toporowski is indeed the decrease of firms' recourse to bank credit as a source of external finance, while for Minsky, "the relevant paradigm is a system with a City or a Wall Street where asset holdings as well as current transactions are financed by debts" (Minsky1975). That paradigm, so described, is no more consistent with economic reality.

The financial fragility of the FIH is usually ${ }^{11}$ measured by the financial leverage ratio. This is commonly computed as stock of debt over stock of assets $(D / A)$, or stock of debt over stock of equity $(D / E)$, or as debt over internal finance $(L / F u$, where $F u$ represents retained earnings and $L$ new flow of loans). Whichever the measure used, the CMI demonstrates how the leverage ratio felt, since the increase in the issue of equity reduced both loans and the stock of debt. More specifically, referring to the second of these measures $(D / E)$, since - as shown by the CMI - the inflation of capital markets would lead to both an increase in the value of equity and a decrease in debt, the leverage ratio would dramatically fall.

A further element of weakness of the FIH, emerging from the analysis of Toporowski, refers to its relation to the business cycle. The financial fragility (and therefore the leverage of firms) in the FIH is pro-cyclical; A booming economy allows for the validation of investment and financing decisions, hence expectations become increasingly optimistic. These are shared between firms and banks. The latter, therefore, are willing to

11 Minsky himself referred to this ratio, e.g. 'The greater the leverage an investing unit uses, i.e., the greater the ratio of debt to internal financing, the greater are such excess contractual cash-flow commitments' (Minsky, 1975, p.108). 
grant the credit required by the former, since both try to take advantage of the positive economic situation. However, Toporowski shows that the indebtment level of firms is on the contrary anti-cyclical, and so is leverage, since both decrease during the upswing phases of the economic cycle. In particular, the reduction of leverage is accelerated by the double effect of an increase in the value of equities on the one side, and a decrease of debt on the other side; “[...] when an economic boom provides them with plentiful sales revenue, firms actually reduce their debt financing, and even replace it with equity (common stock) as the stock market flourishes" (Toporowski, 2000, p. 27). These aspects of the CMI seem bound to invalidate the FIH, which, according to Toporowski, "may still be valid if equity is regarded like debt as a liability of firms" (Ibid).

With respect to Steindl's analysis, Toporowski shows that the structural changes determined by the financialization of the economy had a direct impact on firms' savings, which increased. How this can be linked to the analysis by Minsky and to the subprime crisis is the theoretical dilemma that we will try to solve in the next section of the paper, by combining the theoretical framework of Minsky with the CMI of Toporowski. In doing so, we believe we will fill the gaps identified in our literature review.

\section{THE FIH AND CMI COMBINED: A STRUCTURAL INTERPRETATION OF THE CRISIS}

One of the main conclusions of the CMI, is that the asset inflation determined a major change in the way firms finance their investment and production decisions. The inflow guaranteed by equities substituted debt as main source of finance. As with any debt, there is a correspondent credit. This paradigmatic change did not impact firms exclusively; indeed banks had to adapt to the new economic environment. Toporowski (2000) observes how, since the 1970s, banks went through — and in part were forced through - major changes. They had indeed lost their best customers, namely companies, which started financing capital accumulation through retained profits, whose liquidity was then topped off via equity emission. This indirect equity financing of investment broke the bank-firm relation, which was at the core of capitalist societies, up to their financialization. Banks therefore started focusing their profit-seeking efforts into other activities, such as "fee-related business in derivatives and debt obligations markets, and towards lending in the property market and to other risky customers that banks had hitherto treated with much more caution" (Ibid). 
Referring to Section 2, we could say that banks' business shifted from $\mathrm{S}_{\mathrm{F}}$ to $\mathrm{S}_{\mathrm{H}}$. The repeal of the Glass-Steagall Act in 1999 can therefore be seen as an institutionalization of this change, and as Minsky (1986, Ch.10) notices, the distinction between commercial banks and other financial institutions had already become mainly notional since the 1960s.

This analysis of banks by Toporowski can represent a bridge between his CMI and the FIH. We believe that the two theories are somehow complementary and, if combined, can provide for a structural explanation of the crisis by not only overcoming the most contingent aspects of the analysis of Minsky, but allowing as well to identify the endogenous forces which made financial instability unburdening in the real estate market.

Something that is often underestimated ${ }^{12}$ in the analysis of the FIH is the fundamental role played by the banking sector. Banks - a term used by Minsky to refer generally to financial institutions in the FIH - represent arguably one of the major determinants of the economic trends. In Keynes's words "Banks hold the key position in the transition from a lower to a higher scale of activity" (Keynes, 1973, p.222). This derives from their capacity to create money ${ }^{13}$. They ultimately decide the extent by which the cost of an investment can overcome the internal sources of finance, providing for the needed credit. Hence - while not directly determining them - they fuel the business cycles, supplying credit during booms and cutting it during recessions (the infamous credit crunch). Banks indeed in the FIH are the units which allow firms — and the economic system - to undertake increasingly fragile positions.

It is important to bear in mind that this behavior of banks is not irrational; simply they live in the same economic environment as firms, with which they share the “expectational climate" (Minsky, 1986, p. 255). Due to radical uncertainty, - another key element of Minsky's analysis — the euphoric expectations pushing firms to expand their business during booms is the same optimism motivating banks to expand credit.

But their importance in the FIH does not rely exclusively on the centrality of their role for the economy. In Minsky's analysis, banks are indeed very active agents: "They actively solicit borrowing customers, undertake financing commitments, build connections with business and other bankers, and seek out funds" (Minsky, 1986, pp. 256-257). Furthermore, in a Schumpeterian ${ }^{14}$ way, banks are considered innovative agents, able to expand credit - with a given amount of reserves — and overcome limitations imposed by

12 Notable exceptions are represented by Nasica (2010) and Wray (1992).

13 On endogeneity of money in Minsky see Wray (1992).

14 For precise reference see the note 8 (Schumpeter, 1951, p.153). 
financial authorities, thanks to liability management. These peculiarities make banks the engine guiding the economy toward an unsustainable path.

The idea we are proposing is that banks are the endogenous destabilizer ${ }^{15}$ of the FIH, and - once they shifted their business, as described by the CMI — the destabilizing tensions described by Minsky, unburdened in some of their new core businesses ${ }^{16}$ as securitization and the real estate.

\subsection{Updating the Financial Instability Hypothesis}

As we tried to make clear above in this paper, the Minsky's analysis is grounded in a thorough analysis of the structure of the economy, which, as the author observed in many occasions, cannot be considered universal and unchangeable.

"Capitalism is a dynamic, evolving system that comes in many forms. Nowhere is

this dynamism more evident than in its financial structure...." (Minsky and

Whalen, 1996, pp. 2-3)

It seems therefore sensible to try to use his economic framework to update the FIH in light of the changes that have occurred in the financial system.

In this "updated" FIH, the dynamic revolves around the mortgage market, which, as shown above, is the new core business of banks. The purchase of dwellings by households represents the new "investment decision," which substituted the increase in the stock of productive capital by firms, around which the original FIH was developed. The two prices to be compared are, on the one side, the price of the house increased by an amount which depends on the cost of the mortgage to protect banks against the lender's risk; and on the other side, the expected value of the house (actual price plus capital gains), decreased by an amount to protect the households by the borrower's risk. These amounts, linked to the risks of the two units in play, are the aforementioned cushions of safety, whose size adapts according to expectations - decreasing during booms (and euphoria) and increasing during recessions. In the years preceding the subprime crisis, institutional factors concurred in making the risk perceived by both borrowers and lenders almost negligible and led to the shrinking of the cushions of safety. First, houses were considered a highly secure asset, and second, financial engineering protected banks against the lenders' risk. This latter

15 This definition belong to Minsky, which entitled a section of his chapter on banks 'Banking as an endogenous destabilizer: the central bank as the lender of last resort' (pp.279 Minsky, 1986).

16 A rather similar perspective is put forward by Dymski (2010). However the author iden- tifies exclusively in the deregulation the cause of the shift of banks' business, not taking into account the role of firms. 
component, which played a major role in the dynamics leading to the crisis of 2007, was a major characterizing feature of recent American capitalism, and will be analyzed in more detail in the next section.

These factors favored the boom of the house market. The resulting euphoric expectations were shared by households and banks, since both live in the same world characterized by radical uncertainty. Sticking to ornithological metaphors, rather than a "black swan," it was a matter of two inductivist turkeys (Russell, 1973): households and banks (with the harmful peculiarity that, due to endogeneity of money, one of the two turkeys was in control of the feeding). This new two-price theory is characterized by the apparent comparison between a flow and a stock. On the one hand, the outflow of money to purchase the capital asset (house), and on the other hand, the expected value of the asset (price of the house plus capital gain). As we recalled, in the original FIH, the two prices were two flows: the first was still the outflows of money to purchase the asset, while the second was the inflow of money represented by the expected entrepreneurial returns. This peculiarity of the updated FIH is due to the increasingly common speculative behavior of units - purchasing houses in the expectation of capital gains which are then transformed in a flow (hence monetized) through selling, refinancing, or simply using the value of the house as collateral. This inflow of money arising from debt was the cornerstone of US capitalism heading to the crisis, since it served a double scope: financing consumption and foraging the asset inflation. Debt was used to keep up consumption in the face of a declining wage share in a context of increased income inequality ${ }^{17}$. Similarly, the money used to purchase assets as described by the CMI had its origin in the credit market.

"The standard view is that liquidity inflows into capital markets come from 'saving' out of income, and the rise in security prices encourages firms to increase their productive investment in order to match that saving. However, such excess liquidity could just as easily come from bank credit inflation." (Toporowski, 2009b, p.892)

The remainder of the FIH is unchanged, with households refinancing the mortgages as the new Ponzi units of the taxonomy, while the euphoric expectations due to a prolonged period of stable growth and the subsequent decrease of prudential behaviors - in this updated version - are the same as in the original. Once again, when the burden of Ponzi

17 The role of inequality in the increased financial fragility of the US has been highlighted by several authors for a comprehensive literature review see van Treeck (2013). 
households became unsustainable, the crisis emerged, the housing bubble burst, and a Minsky Moment occurred.

\subsection{Banks as Endogenous Destabilizer, Some Data}

In this last section, we will try to show how the analysis we developed finds confirmation in the data.

Starting from the CMI, the shift of banks' business is glaring in Figure 2, which shows the ratio of real estate loans over commercial and industrial loans in commercial banks' balance sheets from 1947 until now in the U.S. economy. From the end of World War II, the amount of commercial and industrial loans was systematically higher than those related to real estate. The situation reversed starting in the 1980s, and reached its peak in 2010, when the latter were three times higher than the former.

The substantial growth in the level of credit granted by banks to households was made possible by the inflation in the price of assets (as described by the CMI), against which households could increasingly borrow. In particular, the decade between 1996 and 2006 witnessed a constant increase in the price of houses, whose value between 1997 and 2006 rose by $124 \%$ (according to the Case-Shiller Index). Financial institutions, with the aim of exploiting this dynamic, dramatically decreased their credit standard and - just as described by the FIH - they let the cushions of safety for this type of borrowing become increasingly narrow, ultimately encouraged by the "euphoric expectations" arising from radical uncertainty. The average Loans-to-Value ratio reached its peak of 94\% in 2005. 
Figure 2 Real estate over Commercial and Financial Loans, U.S. Commercial Banks

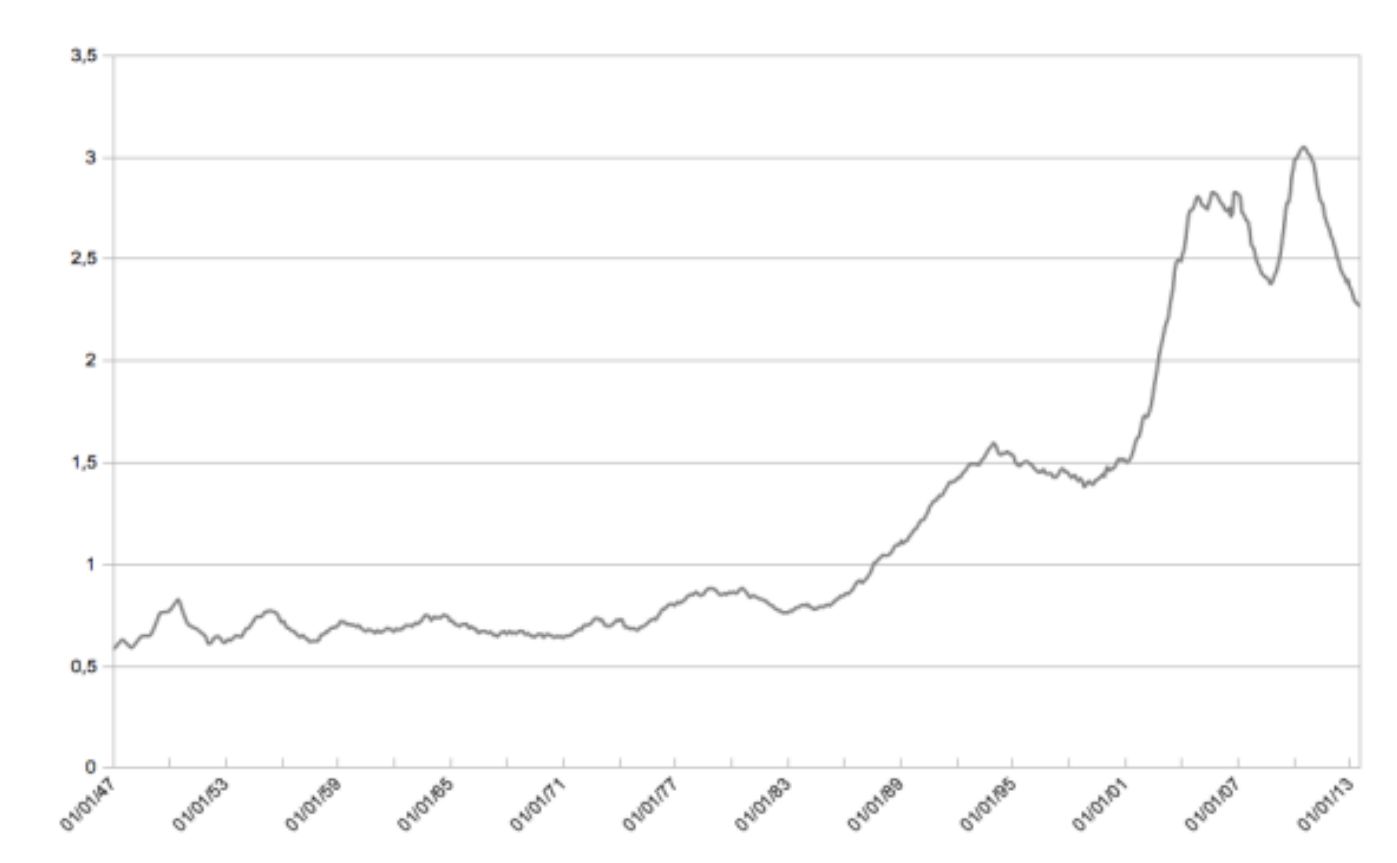

Source: Federal Reserve Economic Data

It is important to notice how radical uncertainty and the subsequent pro-cyclical expectations did not affect the financial position of corporations, since - due to overcapitalization - their position could have been steadily classified as hedge according Minsky's taxonomy. As calculated by Bates (2009), the average cash-to-assets ratio more than doubled between 1980 and 2006, increasing from $10.5 \%$ to $23.2 \%$.

Furthermore, the active and innovative behavior of banks, highlighted by the FIH, played a particularly relevant role in the crisis of the 2007, since the proliferation of new financial instruments stimulated the expansion of credit and discouraged prudential behaviors, as the risk was spread by banks. Lavoie (2009) individuates four main steps in the evolution of mortgage-related financial innovations. First mortgages became securities (Mortgage Backed Securities, MBS) and as such, they could be sold, allowing them to externalize the risk they carried. Then asset-backed commercial paper (ABCP) was issued by financial institutions willing to buy the MBS. A further step was represented by the Collateralized Debt Obligation (CDO). Mortgage-backed securities were divided into tranches according to their riskiness and potential returns, and then (mainly the lower rated ones) grouped in CDOs. This "financial packaging" — the so-called "structured finance" allowed for the creation of nebulous financial products, able to receive safe ratings, albeit being highly risky. Finally, the infamous credit default swaps (CDS) allowed banks to get an insurance in case a security defaults. These innovations made the lender's risk to be 
perceived as practically negligible or as underlined by Kregel (2008), they detached the issuer from the holder of the credit (hence the evaluator of the credit worthiness from whom was running the lender's risk) and boosted the destabilizing dynamic. Households saw their financial positions becoming increasingly fragile. Up to the moment in which the weight of speculative and Ponzi (households) units became unsustainable, the subprime mortgages which used to represent an exception - 8\% of total mortgages in 2003 - became almost consuetudinary, reaching the climax of one-fifth of new originated mortgages ${ }^{18}$ in 2005 and 2006, making the crisis inevitable. All these data show a how the subprime crisis was the outcome of a dynamic which finds perfect explanation in the updated FIH. What we believe it is important to stress is that this updated version includes no theoretical novelty. It is just the outcome of the application of Minsky's Financial Keynesianism to the most recent US capitalism.

\section{CONCLUSION}

In summing up the main findings of our investigation, we revert to the analysis of Steindl in order to make our point clearer and to build a bridge with existing theories. We believe that the asset inflation made loans more easily available to households allowing their debt to grow and making their saving $\left(\mathrm{S}_{\mathrm{H}}\right)$ decrease, while capital asset inflation made firms less dependent on banks' loans, favoring an increase in their savings $\left(\mathrm{S}_{\mathrm{F}}\right)$. This led banks to shift their business focus from firms to households and contributed to the rise of household debt. The money inflow deriving from debt was used by households to purchase assets and consumption goods, creating a dynamic in which $\mathrm{S}_{\mathrm{F}}$ was kept low while $\mathrm{S}_{\mathrm{H}}$ increased. Hence - albeit the causal link of the enforced indebtedness described by Steindl was not really reversed - the new financing behavior contributed to the start of a dynamic which led households to become increasingly indebted, and ultimately caused the crisis.

We are not advocating that banks are "the bad guys." Identifying a scape goat to blame is not the goal of this paper. This, first of all, would be wrong, because it is important to bear in mind that the word "banks" was used by Minsky in a rather general way, referring to the whole financial system, and because economic phenomena are the results of a complex interaction of a multitude of factors. Furthermore, it would also be harmful because

18 See Joint Center for Housing Studies of Harvard University (2008). 
it would focus the attention on a wrong target, leaving the mechanisms which make financial capitalism fragile and untouched (in practice justifying a Gattopardo's approach to reforms). The combination of profit seeking banks, radical uncertainty, unregulated financial markets, and endogenous money (just as described by Minsky) makes the system endogenously unstable and the FIH still up-to-date, no matter the market where it displays. 


\section{REFERENCES}

Bates, H.W., Kahle, K.M., and Stulz, R. M., 2009. Why Do U.S. Firms Hold So Much More Cash than They Used To? The Journal of Finance, LXIV(5)

Bellofiore, R. and Halevi, J., 2009. A Minsky Moment? The Subprime Crisis and the New Capitalism. In C. Gnos and L.P. Rochon, editors, Credit, Money and Macroeconomic Policy. A Post-Keynesian Approach. Cheltenham, Edward Elgar,

Davidson, P., 2008. Is the Current Financial Distress Caused by the Subprime Mort- gage Crisis a Minsky Moment? Or is it the Result of Attempting to Securitize Illiquid Noncommercial Mortgage Loans? Journal of Post-Keynesian Economics, 30: 669676.

Delli Gatti, D., Gallegati, M., and Minsky, H.P., 1994. Financial Institutions, Economic Policy and the Dynamic Behavior of the Economy. Working Paper No. 126, The Levy Economics Institute of Bard College

Duca, J.V., Muellbauer, J., and Murphy, A. House Prices and Credit Constraints: Making Sense of the U.S. Experience. The Economic Journal, (121):533-551, 2011.

Dymski, G.A., 2010. Why the Subprime Crisis is Different: a Minskyian Approach. Cambridge Journal of Economics.

J. Galbraith, K. and D Munevar Sastre. The generalized 'minsky moment'. In D. B. Papadimitriou and L. R. Wray, editors, The Elgar Companion to Hyman Minsky, chapter 14. Edward Elgar, 2010.

Joint Center for Housing Studies of Harvard University, 2008.The State of the Nation's Housing Technical report, Harvard.

Kalecki, M., 1937. The Principle of Increasing Risk. Economica, 4(16), 1937.

Keynes, J.M., 1937. The General Theory of Employment. The Quarterly Journal of Economics.

1973. The "ex ante" theory of the interest rate. In The Collected Writings of John Maynard Keynes, volume XIV: The General Theory and After: Defence and Development [1938], pages 215-23. London: Macmillan for the Royal Economic Society.

Kregel, J., 2008. Minsky's Cushion of Safety: Systemic Risk and the Crisis in the U.S. Subprime Mortgage Market. Public Policy Brief No. 93.The Levy Economics Institute of Bard College.

2010. Is this the Minsky Moment for Reform of Financial Regulation? Working Paper No. 586. Levy Economics Institute of Bard College, The Levy Economics Institute and University of Missouri Kansas City.

Krugman, P., 2011. Mr. Keynes and the Moderns. Prepared for the Cambridge conference commemorating the 75th anniversary of the publication of The General Theory of Employment, Interest, and Money. 
Lavoie, M., 2009. Introduction to Post-Keynesian Economics. Palgrave MacMillan..

Lavoie, M. and Seccareccia, M., 2001. Minsky's Financial Fragility Hypothesis: A Missing Macroeconomic Link? In P. Ferri R. Bellofiore, editor, Financial Fragility and Investment in the Capitalist Economy: The Economic Legacy of Hyman Minsky, volume II. Cheltenham, UK: Edward Elgar.

Macedo e Silva, A.C., 2008-09. Missing Details and Conspicuous Absences: from the Treatise to the General Theory. Journal of Post Keynesian Economics, 31 (2):325.

Minsky, H.P., 1975. John Maynard Keynes. Columbia University Press.

1985.The Legacy of Keynes. The Journal of Economic Education, 16 (1),

1986. Stabilizing an Unstable Economy. Yale University Press, New Haven and London (2008),

1992. The Financial Instability Hypothesis. Working Paper No. 74. The Levy Economics Institute of Bard College.

1996. Uncertainty and the Institutional Structure of Capitalist Economies. Journal of Economic Issues, XXX(2).

Minsky, H.P., and Whalen, C.J., 1996. Economic Insecurity and the Institutional Prerequisites for Successful Capitalism. Working Paper No. 165. The Levy Economics Institute of Bard College .

Nasica, E., 2010. Rational and Innovative Behaviours at the Core of Financial Crises: Banking in Minsky's Theory. In The Elgar Companion to Hyman P. Minsky. Northampton,Edward Elgar.

Onaran, O., Stockhammer, E., and Grafl, L., 2011.Financialisation, Income Distribution and Aggregate Demand in the USA. Cambridge Journal of Economics, 35: 637-661.

Orhangazi, O., 2008. Financialisation and Capital Accumulation in the Non-Financial Corporate Sector: A Theoretical and Empirical Investigation on the US Economy: 1973-2003. Cambridge Journal of Economics.

Papadimitriou, D.B. and Wray, L.R., 1997. The Economic Contributions of Hyman Minsky: Varieties of Capitalism and Institutional Reform. Working Paper No. 217. Levy Economics Institute of Bard College.

Russell, B., 1973. On Induction. In The Problems of Philosophy. (1972) .

Schumpeter, J.A., 1951. The Creative Response in Economic History. In Richard V. Clemence, editor. Essays on Economic Topics of J. A. Schumpeter, pages 216-226. Kennikat Press.

Steindl, J., 1952. Maturity and Stagnation in American Capitalism. Oxford Institute of Statistics Monograph No. 4, Oxford: Basil Blackwell.

Taleb, N., 2010. The Black Swan: the impact of the highly improbable (2nd ed.). London: Penguin. 
Toporowski, J., 2000. The End of Finance: The Theory of Capital Market Inflation, Financial Derivatives and Pension Fund Capitalism. Routledge: London.

2009. The Economics and Culture of Financial Inflation. Competition \& Change, 13(2):145-156, June 2009a.

2009. Corporate limited liability and the financial liabilities of firms. Cambridge Journal of Economics, 885-893, 2009b.

United States International Trade Commission, 2010. Small and Medium-Sized Enterprises: Overview of Participation in U.S. Exports. Technical report, 2010.

van Treeck, T., 2009. A Synthetic, Stock-Flow Consistent Macroeconomic Model of 'Financialisation'. Cambridge Journal of Economics, 33(3):467-493. 2013. Did inequality cause the US financial crisis? Journal of Economic Surveys,

Wray, L.R., 1992. Minsky's Financial Instability Hypothesis and the Endogeneity of Money. In Steve Fazzari and Dimitri Papadimitriou, editors, Financial Conditions and Macroeconomic Performance: Essays in Honor of Hyman P. Minsky, pages 161-180. M.E.Sharpe,

2012. Global Financial Crisis: A Minskyan Interpretation of the Causes, the Fed's Bailout, and the Future. Working Paper No. 711. Levy Economics Institute of Bard College. 